\title{
Erratum: YAP determines the cell fate of injured mouse hepatocytes in vivo
}

Norio Miyamura, Shoji Hata, Tohru Itoh, Minoru Tanaka, Miki Nishio, Michiko Itoh, Yoshihiro Ogawa, Shuji Terai, Isao Sakaida, Akira Suzuki, Atsushi Miyajima \& Hiroshi Nishina

Nature Communications 8:16017 doi: 10.1038/ncomms16017 (2017); Published 6 Jul 2017; Updated 7 Aug 2017.

The financial support for this Article was not fully acknowledged. The Acknowledgements should have included the following:

This work was supported by a Nanken-Kyoten grant from Tokyo Medical and Dental University (TMDU).

(c) Open Access This article is licensed under a Creative Commons Attribution 4.0 International License, which permits use, sharing, adaptation, distribution and reproduction in any medium or format, as long as you give appropriate credit to the original author(s) and the source, provide a link to the Creative Commons license, and indicate if changes were made. The images or other third party material in this article are included in the article's Creative Commons license, unless indicated otherwise in

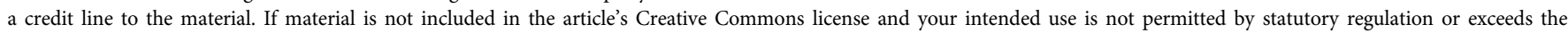
permitted use, you will need to obtain permission directly from the copyright holder. To view a copy of this license, visit http://creativecommons.org/licenses/by/4.0/

(C) The Author(s) 2017 